\title{
Matrix Metalloproteinase Activity in the Stromal Cell of Giant Cell Tumor of Bone
}

\author{
Alexander Rabinovich ${ }^{1}$, Isabella W. Y. Mak ${ }^{1,2}$, Robert W. Cowan ${ }^{1,2}$, Robert E. Turcotte ${ }^{3}$, \\ Nigel Colterjohn ${ }^{\dagger, 1,2}$, Gurmit Singh ${ }^{1,2}$ and Michelle Ghert ${ }^{*}, 1,2$ \\ ${ }^{I}$ McMaster University, Hamilton, Ontario, Canada \\ ${ }^{2}$ Juravinski Cancer Centre, Hamilton Health Sciences, Hamilton, Ontario, Canada \\ ${ }^{3}$ McGill University Health Centre, Montreal General Hospital, Quebec, Canada
}

\begin{abstract}
Giant cell tumor of bone (GCT) is a destructive and potentially metastatic bone tumour in which the characteristic giant cells have classically been considered the culprits in bone destruction. However, the neoplastic element of the tumour consists of propagative osteoblast-like stromal cells that may play a role in bone resorption. The objectives of this study were to determine the expression and activity of the gelatinases, matrix metalloproteinase (MMP)2 and -9 , in GCT stromal cells, and to determine if these cells have bone-resorbing capabilities. We performed immunohistochemistry on clinical specimens, and real-time polymerase chain reaction (PCR) and zymography on cell lysates and conditioned media from cultured clinical GCT specimens in order to evaluate the expression and activity of MMP-2 and-9 in GCT stromal cells. Our results support the fact that GCT stromal cells express MMP-2 and MMP-9 and are capable of gelatin degradation in vitro. These cells may therefore play a role in bone destruction in GCT.
\end{abstract}

\section{INTRODUCTION}

Giant cell tumor (GCT) of bone represents $3-8 \%$ of all bone tumors and is a benign-aggressive osteolytic tumor with metastatic potential [1-4]. GCT of bone commonly occurs in the second to fifth decades of life in the weight bearing regions of the knee, but can occur anywhere in the skeleton $[1,5]$. Patients most commonly present with pain, and a few present with a pathologic fracture [1-4]. The current management of GCT of bone is surgical intervention, ranging from intralesional curettage to resection and reconstruction $[1,5-8]$. Despite aggressive surgical management, the average recurrence rate is $15 \%$ (range $2.5-45 \%$ ) [9]. Up to $10 \%$ of patients undergo malignant transformation at recurrence, and up to $5 \%$ have pulmonary metastases [1013].

The histology of GCT of bone suggests three distinct cell types: the osteoclast-like multinucleated giant cells, the mononuclear cells of monocytic-macrophage origin, and the spindle-like mononuclear stromal cells of mesenchymal origin [14-21]. The giant cells have classically been considered the active cells in bone resorption [15, 20, 22, 23]. However, recent evidence suggests that the neoplastic elements in GCT are the stromal cells of mesenchymal origin which express characteristics of osteoblastic precursors [14, 24]. The mechanism by which the multinucleated giant cells and osteoblastic-like stromal cells cause bone destruction is

*Address correspondence to this author at the 699 Concession Street, Hamilton, Ontario, L8V 5C2 Canada; Tel: (905)-387-9495 ext 64902; Fax: (905)-575-6343; E-mail: michelle.ghert@jcc.hhsc.ca

†Deceased of considerable interest in the development of targeted therapeutic strategies for GCT.

Matrix Metalloproteinases (MMPs) are proteases involved in numerous cellular functions, such as bone matrix remodeling and angiogenesis, and have been implicated in numerous tumors, such as bone, breast and colon cancers [25-29]. MMP-2 and MMP-9 play a key role in basement membrane extracellular matrix degradation, which can lead to invasion and metastasis. In addition, MMP-2 and -9 are capable of degrading denatured type-I collagen (gelatin), leading to local bone destruction [25, 26, 30-36]. MMP-2 and MMP-9 are therefore key factors in tumor pathophysiology, and their role in GCT of bone is intriguing.

We hypothesize that the osteoblast-like stromal cells of GCT express the gelatinases MMP-2 and -9 , and that these cells are capable of degrading bone matrix in vitro. In order to test our hypothesis, we used archival clinical specimens of GCT and examined the specimens using immunohistochemistry for MMP-2 and MMP-9. In addition, we cultured specimens of GCT and used real-time PCR and zymography to confirm our findings in vitro.

\section{MATERIALS AND METHODS}

\section{Patient Population}

We obtained approval from our institution's Biohazard and Ethics Review Boards for the collection of patient demographics and clinical specimens. The patients were enrolled into the study from the clinical practice of two Orthopaedic Oncology surgeons as they presented from 
Table 1. Patient Demographics and Surgical Management

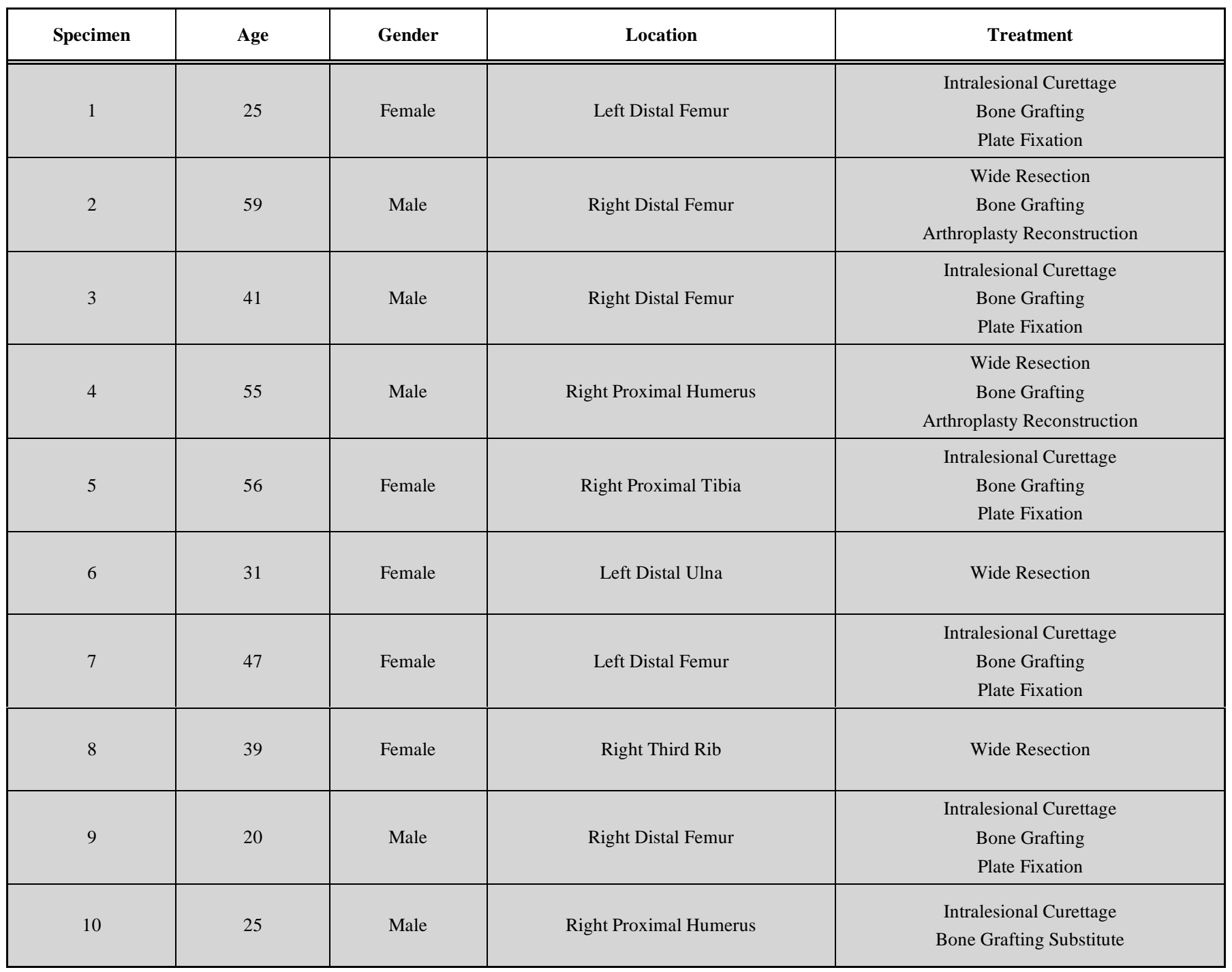

January 2005 - December 2007. Each patient signed informed consent prior to enrolling in the study. A musculoskeletal pathologist verified all tissue specimens for the pathologic diagnosis of GCT. The demographics and surgical management of the patients are summarized in Table I. Five patients were female, five were male, and the average age at presentation was 39.8 years.

\section{Immunohistochemistry for MMP-2 and -9}

Paraffin-embedded archival tissue specimens from ten patients were cut to $5 \mu \mathrm{m}$ and mounted onto slides. Tissue slides were deparaffinized in several changes of xylene and rehydrated in sequential diluted ethanol before rinsing in trisbuffered saline with $0.1 \%$ Triton X-100 (TBS-T). Slides were blocked for endogenous peroxidase activity by incubation in $3 \%$ hydrogen peroxide for 10 minutes, washed in TBS-T and then treated with 5\% normal goat serum for 30 minutes to block nonspecific IgG binding. Sample slides were incubated at room temperature for 1 hour in 1:100 dilution of primary antibodies MMP-2 (RDI, CA-4001) and
MMP-9 (Calbiochem, 56-2A4) in a moist chamber. Slides were then rinsed three times in TBS-T, and incubated for 30 minutes at room temperature with a 1:500 dilution of secondary anti-mouse IgG (Sigma, Germany). Following another wash in TBS-T and an incubation with streptavidinbiotin complex (ABC reagent, Vector Burlingame, CA), substrate color was developed for 2 to 10 minutes at room temperature using a liquid 3,30-diaminobenzidine (DAB) substrate-chromogen solution kit (DAKO, USA). Slides were counterstained in hematoxylin, dehydrated in graded ethyl alcohol $(70 \%, 90 \%, 100 \%)$, mounted in Permount, and examined under a light microscope. Immunohistochemistry was performed in triplicate. The specimens were subjectively graded for immunohistochemistry staining as none (0), faint (1), strong in less than $50 \%$ of cells (2), or strong in over $50 \%$ of cells (3).

\section{Primary Cell Cultures}

Tumor tissue was collected intraoperatively from GCT patients and stored in Dulbecco's modified Eagle's medium 
(Gibco) containing 10\% fetal bovine serum, $2 \mathrm{mM} \mathrm{L-}$ glutamine, $100 \mathrm{U} / \mathrm{ml}$ penicillin, and $100 \mu \mathrm{g} / \mathrm{ml}$ streptomycin. The specimens were cut in the media and the resulting cell suspension with small pieces of tissue were passed via a 24gauge needle into $25 \mathrm{~cm}^{2}$ vented cell culture flasks and incubated at $37^{\circ} \mathrm{C}$ in a humidified atmosphere of $5 \% \mathrm{CO}_{2}$ and $95 \%$ air. The culture media was changed every 2 to 3 days. At $80 \%$ confluence, the cell cultures were divided by digesting with $0.1 \%$ trypsin-EDTA solution and splitting the resulting suspension into new flasks. Primary GCT stromal cell cultures were established using the techniques described by Ghert et al. [37]. In brief, the giant cell/monocyte fraction is eliminated with repeated passages of the cells so that a pure stromal cell culture is maintained. Passages 6-10 were used for the following experiments.

\section{Real-Time Polymerase Chain Reaction (Real-Time PCR)}

Real-Time PCR analysis was performed using the primers for MMP-2 forward 5' ACATCAAGGGCATTCA GGAG 3' and reverse 5' CTGAGCGATGCCATCAAATA 3', and MMP-9 forward 5' TCTTCCCTGGAGACCTGAGA 3' and reverse 5' ATTTCGACTCTCCACGCATC 3'. RNA was extracted from cell cultures using the Superscript ${ }^{\mathrm{TM}}$ Real-Time PCR System (Invitrogen, Mississauga, ON) according to the manufacturer's direction. Real-Time PCR reactions were performed on a MiniOpticon Real-Time PCR Detection System (Bio-Rad Laboratories, Inc., Mississauga, Ontario, Canada) using the iQ SYBR Green Supermix (Cat. \# 170-8882, Bio-Rad Laboratories) according to the manufacturer's instructions. The house keeping gene (human GAPDH) was used as an internal control, forward 5' CATGAGAAGTAT GACAACAGCCT 3' and reverse 5' AGTCCTTCCACGATACCAAAGT 3'. Expression was determined relative to human fetal osteoblasts (hFOB 1.19, CRL-11372, ATCC) as a system control. The reaction was run in a real time thermal cycler (Bio-Rad) as in a traditional PCR: 40 cycles of 15 seconds of denaturation at $94^{\circ} \mathrm{C}, 30$ seconds of annealing at individual optimal temperature (58$60^{\circ} \mathrm{C}$ ), 30 seconds of extension at $72^{\circ} \mathrm{C}$, with a gradient change in temperature to determine the melting curve of the final PCR products. A human osteosarcoma cell line (HOS) was used as a positive control.

\section{Conditioned Media Collection from Primary Cell Cultures}

When the primary cell cultures reached $80 \%$ confluence, the media was changed to serum-free media and incubated for 24 hours at $37^{\circ} \mathrm{C}$ in a humidified atmosphere of $5 \% \mathrm{CO}_{2}$ and $95 \%$ air. Conditioned media was subsequently collected and a 40-fold concentration was obtained using an Amicon Ultra-4 Centrifugal Filter Device (Millipore, Billerica, MA), which retains proteins larger than $10 \mathrm{kDa}$. The conditioned media was aliquoted to Eppendorf tubes and stored at $-80^{\circ} \mathrm{C}$ for subsequent assays.

\section{Zymography Gel Electrophoresis}

Zymography was used to detect the protease activity of MMP-2 and MMP-9 from the conditioned media of primary cell cultures. Zymography is based on sodium dodecyl sulfate polyacrylamide gel electrophoresis (SDS-PAGE) with a copolymerized substrate to identify enzyme activity. A solution of $0.3 \%$ Gelatin from bovine skin, Type B (Sigma, St. Louis, MO, USA) was used as the copolymerized substrate for gelatinase activity of MMP-2 and MMP9. The negative control was serum free media, and positive controls were human osteosarcoma cell line (HOS, ATCC ${ }^{\circledR}$ \#: CRL-1543 ${ }^{\mathrm{TM}}$ ) and a human fibroblast cell line (CCD27Sk, ATCC ${ }^{\circledR}$ \#: CRL-1475 ${ }^{\mathrm{TM}}$ ). For a standard zymogram, $20 \mu \mathrm{l}$ of conditioned media sample was mixed with $10 \mu \mathrm{l}$ of $6 \mathrm{X}$ substrate dye buffer per well. The gel was run at 30 volts through the stacking gel and at 100 volts through the separating gel for 1 hour. The stacking gel was discarded and the separating gel was placed into a glass container with 2.5\% Triton X-100 (Sigma, St. Louis, MO, USA) solution for 30 minutes to remove the SDS. The gel was incubated overnight at $37^{\circ} \mathrm{C}$ in a substrate buffer $(50 \mathrm{mM}$ TRIS, $5 \mathrm{mM}$ $\mathrm{CaCl}_{2}, 0.04 \% \mathrm{NaN}_{3}, \mathrm{pH}$ 8.0). Coomassie Brilliant Blue dye stained the SDS-PAGE and clear bands indicated gelatinase activity. The gels were stored in a wet or dry plastic wrap and digital imaging was used for analysis.

A protease blocking assay was conducted with $0.02 \mathrm{M}$ ethyl enediamine tetraacetic acid (EDTA, EX0534-1, Merck KGaA, Darmstadt, Germany) solution, which was added to a glass dish containing the SDS-PAGE and substrate buffer for overnight incubation after gel electrophoresis. The following day, the gel was washed three times with Milli-Q H2O and stained with Coomassie Brilliant Blue as per the standard zymogram protocol.

A protease activation assay was conducted with $2.5 \mathrm{mM}$ 4-aminophenyl mercuric acetate (APMA, A9563, Sigma, St. Louis, MO, USA) at pH 7.0-7.5. Twenty $\mu$ l of $2.5 \mathrm{mM}$ APMA was added to $20 \mu \mathrm{l}$ of conditioned media sample and incubated for 1 hour at $37^{\circ} \mathrm{C}$ prior to gel electrophoresis. The remaining steps were identical to the standard zymogram protocol.

\section{RESULTS}

\section{Immunohistochemistry}

Immunostaining for MMP-2 and MMP-9 in GCT tissue specimens was performed and representative slides are shown in Figs. (1A, B). A negative control with no primary antibody is shown in Fig. (1C). Positive staining for MMP-2 and -9 was positive in the cytoplasm of the multinucleated giant cells and diffusely positive in the spindle-like stromal cells of GCT. Results were consistent across all ten clinical specimens (Table 2).

\section{Quantitative Real Time Polymerase Chain Reaction (Real-Time PCR)}

To verify our immunohistochemical findings, we used Real-Time PCR to detect MMP-2 and MMP-9 mRNA expression in the GCT stromal cell cultures. Results showed that MMP-2 and MMP-9 mRNA expression was present in GCT stromal cell cultures, with variations in the relative production for respective samples. A representative RealTime PCR graph is shown in Fig. (2). Results represent means and standard deviations from triplicate experiments. Although variations existed from specimen to specimen with 
A

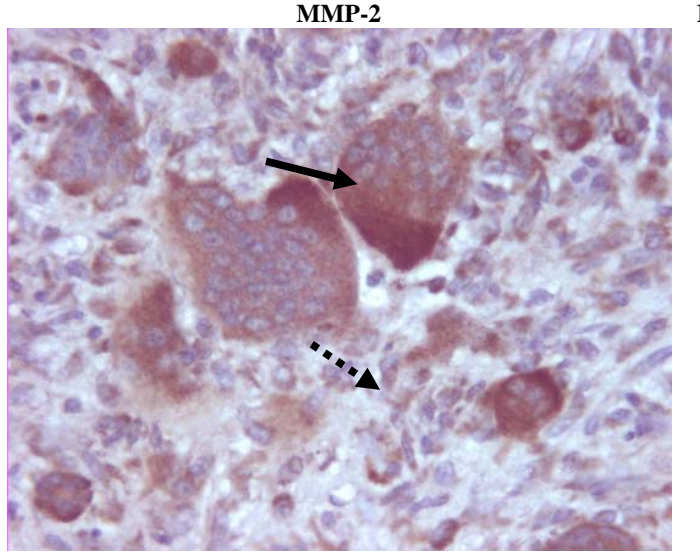

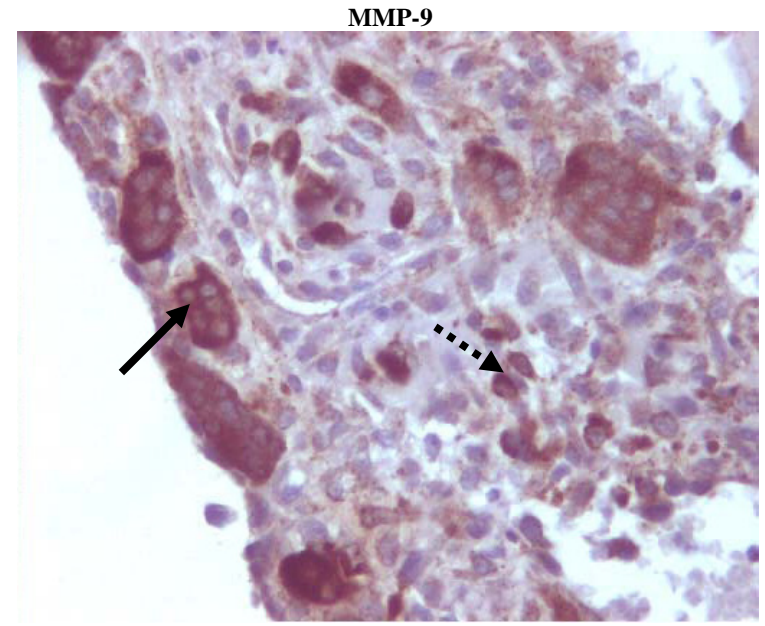

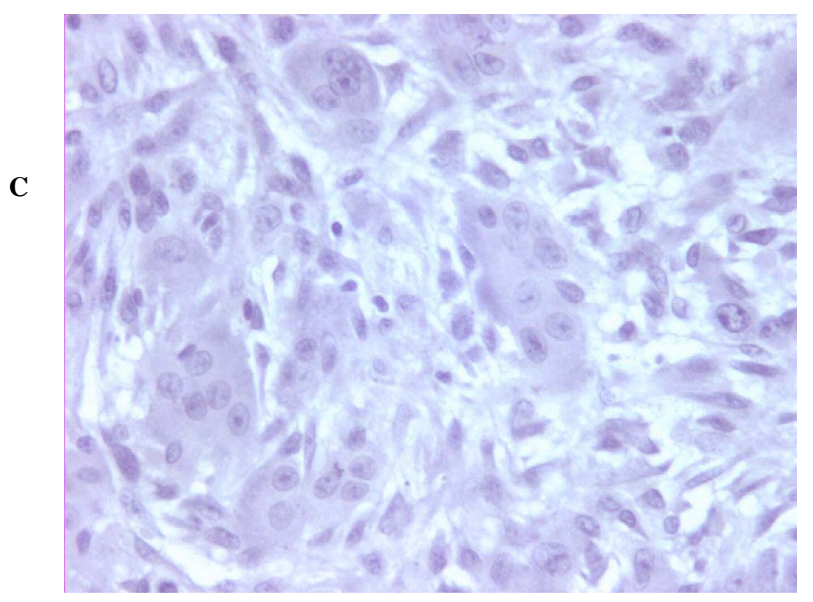

Fig. (1). Representative immunohistochemistry slides of paraffin-embedded GCT of bone tissue specimens for MMP-2 and MMP-9. (A) MMP-2 antibody staining at x400 magnification. (B) MMP-9 antibody staining at x400 magnification. MMP-2 and MMP-9 staining was positive in the cytoplasm of the multinucleated giant cells (solid arrows), and diffusely positive in the spindle-like stromal cells (dotted arrows). (C) Representative paraffin-embedded immunohistochemistry negative control with the absence of a primary antibody (H+E, original magnification $\mathrm{X} 400)$.

Table 2. Immunohistochemistry Results for MMP-2 and -9

\begin{tabular}{|c|c|c|c|c|}
\hline & \multicolumn{2}{|c|}{ MMP-2 } & \multicolumn{2}{c|}{ MMP-9 } \\
\hline Specimen & Stromal Cells & Giant Cells & 1 & 1 \\
\hline \hline 1 & 3 & 3 & 1 & 3 \\
\hline 2 & 3 & 3 & 1 & 3 \\
\hline 3 & 2 & 3 & 1 & 3 \\
\hline 4 & 2 & 3 & 1 & 3 \\
\hline 5 & 3 & 2 & 1 & 3 \\
\hline 6 & 2 & 3 & 1 & 3 \\
\hline 9 & 2 & 3 & 3 & 3 \\
\hline
\end{tabular}

Note: Subjective grading system: $0=$ no expression, 1 = faint expression, 2 = strong expression in less than $50 \%$ of cells, $3=$ strong expression $>50 \%$ cells. 


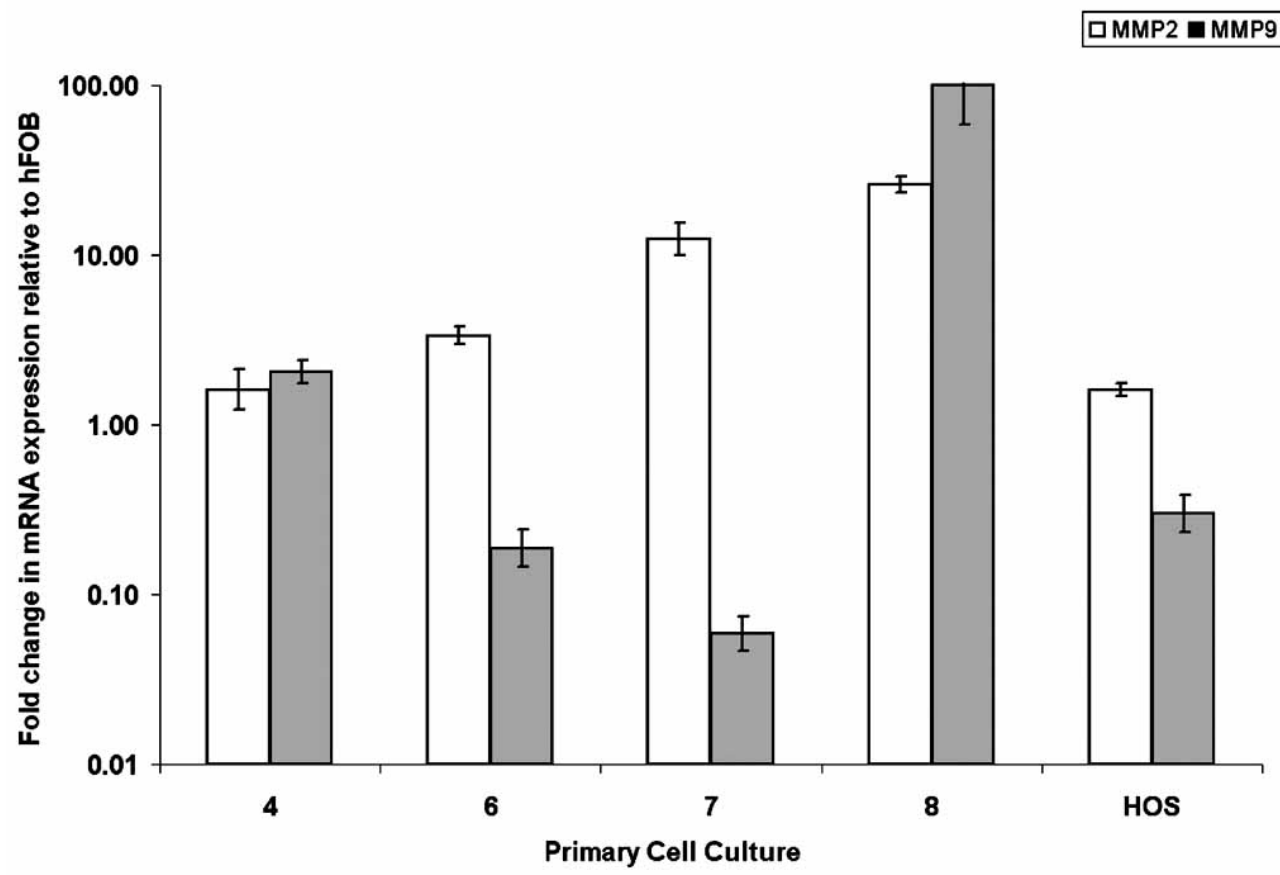

Fig. (2). Relative expression of MMP-2 and MMP-9 mRNA from GCT stromal cell cultures based on Real-Time PCR. Total mRNA isolated from primary cell culture specimens 4, 6, 7, 8, HOS, and hFOB 1.19 were reverse-transcribed using oligo-dT from the Superscript III First Strand Synthesis System (Invitrogen). Real-Time PCR was then used to detect changes in MMP-2 and MMP-9 expression. The $\triangle \triangle \mathrm{CT}$ method was used to calculate the Real-Time PCR fold change using GAPDH mRNA for normalization, and all changes in expression are relative to hFOB 1.19. Three independent Real-Time PCR runs were performed on each sample. A human osteosarcoma cell line (HOS) serves as a positive control.

respect to the relative expression of MMP-2 and -9, all specimens examined showed positive expression of these gelatinases.

\section{Zymography Gel Electrophoresis}

To identify the activity of the gelatinases MMP-2 and MMP-9 in the conditioned media of the primary cell cultures, we used a gelatin impregnated SDS-PAGE (zymogram). After 5 passages, all osteoclast-like giant cells were eliminated and only spindle-like stromal cells were present (Fig. 3). A representative zymogram for specimens 1 and 6

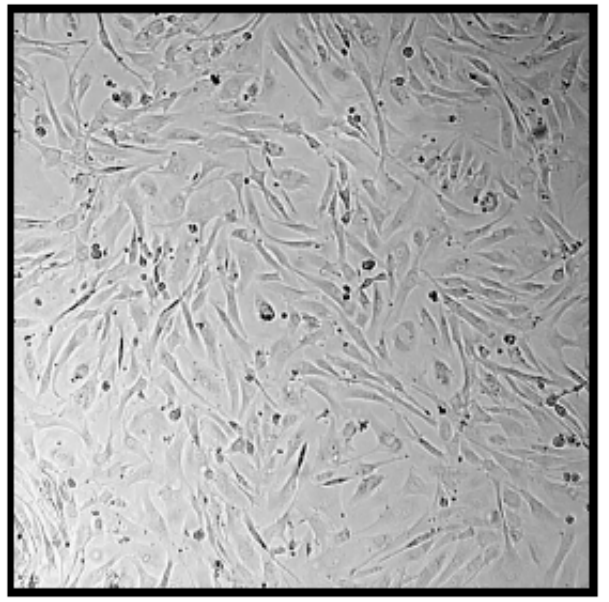

Fig. (3). Representative microscopy of the primary cell cultures after several passages. After 5 passages only spindle-like stromal cells are present and the osteoclasts have been eliminated. are shown in Fig. (4A). We confirmed that conditioned media from GCT stromal cell cultures contained the activated gelatinases MMP-2 and MMP-9. The major form of gelatinase was the zymogen for MMP-2 (72 kDa), followed by the activated form of MMP-2 (62 kDa). To a much lesser extent, the zymogen $(92 \mathrm{kDa})$ and activated $(86$ $\mathrm{kDa}$ ) forms of MMP-9 were also noted. Similar to the results of real-time PCR, the relative amounts of MMP-2 and -9 activity varied from specimen to specimen, but was present in all specimens examined.

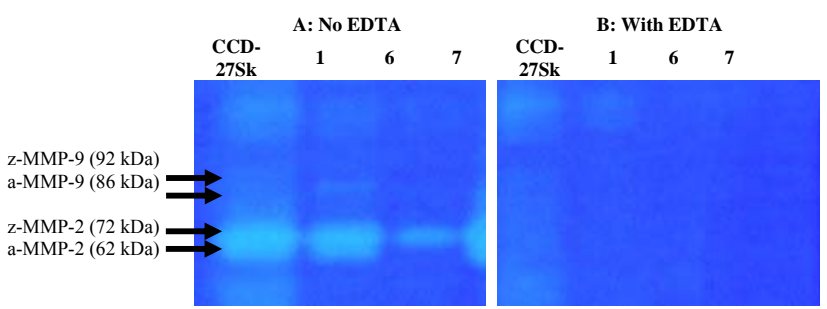

Fig. (4). A-B: Representative blocking zymogram for conditioned media from primary cell cultures. Three primary cell culture specimens are shown (1 and 6). EDTA had a significant inhibiting effect on the gelatinase activity of MMP-2 and MMP-9 in the control (CD-27SK) and the GCT stromal cell cultures. [a=activated, $z=$ zymogen].

MMPs have a metal ion core, and when combined with a metal ion chelating agent (EDTA), it causes them to destabilize and deactivate. A representative blocking assay zymogram is presented in Fig. (4B) for specimens 1 and 6 . Blocking assay zymograms showed complete MMP-2 and MMP-9 deactivation by EDTA, for both the positive controls 
and the conditioned media of the primary GCT stromal cell cultures.

In vitro activation of gelatinases MMP-2 and MMP-9 can be mediated by organomercurial compounds, such as APMA. The activation of MMP-9 was not evident in the conditioned media of the primary cell cultures (data not shown). However, tumor-expressed MMP-2 was activated in GCT stromal cell cultures (Fig. 5).

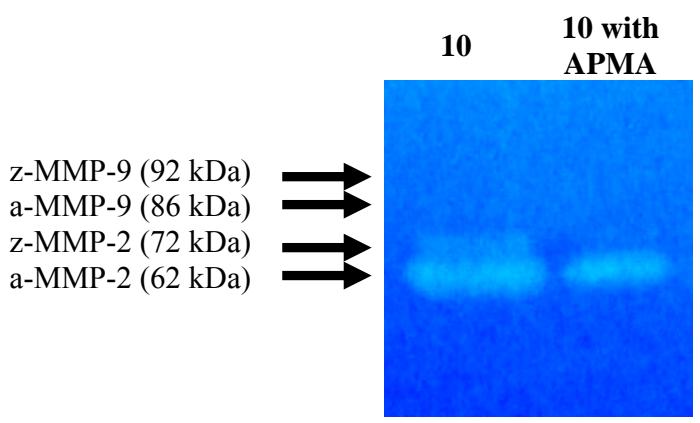

Fig. (5). Representative activated zymogram for conditioned media from GCT stromal cell conditioned media. Activation of MMP-2 zymogen by APMA in the conditioned media from specimen 10. [a=activated, $\mathrm{z}=\mathrm{zymogen}]$.

\section{DISCUSSION}

GCT of bone is a benign-aggressive osteolytic tumor with metastatic potential that affects young adults in their prime. Understanding how this tumor causes bone destruction and local invasion will allow us to develop better treatment options. The culprits in bone destruction in GCT have classically been considered the osteoclast-like multinucleated giant cells, given their high expression of cathepsin $\mathrm{K}$ and their formation of resorption pits in vitro $[15,20,22]$. However, recent evidence suggests that the spindle-like mononuclear stromal cells of osteoblastic origin are the neoplastic elements and may also play a significant role in bone destruction $[37,38]$.

In this study we have shown that the stromal cells of GCT express MMP-2 and -9 in vivo, and that these cells have in vitro gelatinase activity. Our results are consistent with other studies that demonstrated the stromal cells of GCT are stimulated by local cytokines such as tumor necrosis factor alpha (TNF $\alpha$ ) and interleukin-1 (IL-1) to express and produce several angiogenic and proteolytic factors, including vascular endothelial growth factor (VEGF), MMP3, and MMP-9 [39-43]. Rao et al. showed that media from fresh GCT specimens activated MMP-9 in late-passaged stromal cells [31].

MMP-2 and MMP-9 may play a significant role in local tumor osteolysis and invasion in GCT. Bone matrix destruction via type-I collagen degradation (by osteoclasts) leaves behind denatured type-I collagen (gelatin), which the gelatinases MMP-2 and MMP-9 degrade and cause osteolysis $[32,36]$. It has been shown that higher levels of MMP-2 and MMP-9 in axial bone tumors correlate with more aggressive tumors and higher potential for metastasis [27]. We identified a variable ratio of MMP-2 to MMP-9 mRNA expression amongst the different propagative primary cell cultures using quantitative Real-Time PCR analysis and zymography. The variation from specimen to specimen likely represents the heterogeneity characteristic of human clinical specimens. However, we sampled tumors from 10 patients and found that MMP-2 and -9 were expressed in all specimens, strongly supporting our hypothesis that these proteases play a key role in bone resorption in GCT.

The results presented herein further clarify the pathophysiology of GCT and the likely contributive role of the stromal cells in bone destruction. Further research is needed to identify the exact cellular and molecular mechanisms by which the neoplastic stromal cells of GCT function in bone destruction and overall aggressiveness. We are currently investigating the signaling pathways between the giant cells and the stromal cells of GCT with respect to MMP production and activation. We aim to identify the pathways involved in bone destruction in GCT in order to develop inhibitory mechanisms and novel therapeutic modalities.

\section{REFERENCES}

[1] Ghert MA, Rizzo M, Harrelson JM, et al. Giant-cell tumor of the appendicular skeleton. Clin Orthop Relat Res 2002; 201-10.

[2] Szendroi M. Giant-cell tumour of bone. J Bone Joint Surg Br 2004; 86: 5-12.

[3] Szendroi M, Kiss J, Antal I. Surgical treatment and prognostic factors in giant-cell tumor of bone. Acta Chir Orthop Traumatol Cech 2003; 70: 142-50.

[4] Wulling M, Delling G, Kaiser E. The origin of the neoplastic stromal cell in giant cell tumor of bone. Hum Pathol 2003; 34: 983 93.

[5] Randall RL. Giant cell tumor of the sacrum. Neurosurg Focus 2003; 15: E13.

[6] Bini SA, Gill K, Johnston JO. Giant cell tumor of bone. Curettage and cement reconstruction. Clin Orthop Relat Res 1995; 245-50.

[7] Blackley HR, Wunder JS, Davis AM, et al. Treatment of giant-cell tumors of long bones with curettage and bone-grafting. J Bone Joint Surg Am 1999; 81: 811-20.

[8] Capanna R, Fabbri N, Bettelli G. Curettage of giant cell tumor of bone. The effect of surgical technique and adjuvants on local recurrence rate. Chir Organi Mov 1990; 75: 206.

[9] Turcotte RE, Wunder JS, Isler MH, et al. Giant cell tumor of long bone: a Canadian Sarcoma Group study. Clin Orthop Relat Res 2002; 248-58.

[10] Bertoni F, Present D, Sudanese A, et al. Giant-cell tumor of bone with pulmonary metastases. Six case reports and a review of the literature. Clin Orthop Relat Res 1988; 275-85.

[11] Cheng JC, Johnston JO. Giant cell tumor of bone. Prognosis and treatment of pulmonary metastases. Clin Orthop Relat Res 1997; 205-14.

[12] Faisham WI, Zulmi W, Saim AH, et al. Pulmonary metastases of giant cell tumour of the bone. Med J Malaysia 2004; 59 (Suppl F): 78-81.

[13] Kay RM, Eckardt JJ, Seeger LL, et al. Pulmonary metastasis of benign giant cell tumor of bone. Six histologically confirmed cases, including one of spontaneous regression. Clin Orthop Relat Res 1994; 219-30.

[14] Huang L, Teng XY, Cheng YY, et al. Expression of preosteoblast markers and Cbfa-1 and Osterix gene transcripts in stromal tumour cells of giant cell tumour of bone. Bone 2004; 34: 393-401.

[15] Kanehisa J, Izumo T, Takeuchi M, et al. In vitro bone resorption by isolated multinucleated giant cells from giant cell tumour of bone: light and electron microscopic study. Virchows Arch A Pathol Anat Histopathol 1991; 419: 327-38.

[16] Komiya S, Sasaguri Y, Inoue A, et al. Characterization of cells cultured from human giant-cell tumors of bone. Phenotypic relationship to the monocyte-macrophage and osteoclast. Clin Orthop Relat Res 1990; 304-9.

[17] Liu TC, Ji ZM, Wang LT. Giant cell tumors of bone. An immunohistochemical study. Pathol Res Pract 1989; 185: 448-53. 
[18] Wuelling M, Delling G, Kaiser E. Differential gene expression in stromal cells of human giant cell tumor of bone. Virchows Arch 2004; 445: 621-30.

[19] Wulling M, Engels C, Jesse N, et al. The nature of giant cell tumor of bone. J Cancer Res Clin Oncol 2001; 127: 467-74.

[20] Zheng MH, Robbins P, Xu J, et al. The histogenesis of giant cell tumour of bone: a model of interaction between neoplastic cells and osteoclasts. Histol Histopathol 2001; 16: 297-307.

[21] Cowan RW, Mak IW, Colterjohn N, et al. Collagenase expression and activity in the stromal cells from giant cell tumour of bone. Bone 2009; 44: 865-71.

[22] Lindeman JH, Hanemaaijer R, Mulder A, et al. Cathepsin K is the principal protease in giant cell tumor of bone. Am J Pathol 2004; 165: 593-600.

[23] Mak IW, Cowan RW, Popovic S, et al. Upregulation of MMP-13 via Runx2 in the stromal cell of Giant Cell Tumor of bone. Bone 2009; 45: 377-86

[24] Robinson D, Einhorn TA. Giant cell tumor of bone: a unique paradigm of stromal-hematopoietic cellular interactions. J Cell Biochem 1994; 55: 300-3.

[25] Birkedal-Hansen H, Moore WG, Bodden MK, et al. Matrix metalloproteinases: a review. Crit Rev Oral Biol Med 1993; 4: 197250 .

[26] Deryugina EI, Quigley JP. Matrix metalloproteinases and tumor metastasis. Cancer Metastasis Rev 2006; 25: 9-34.

[27] Gokaslan ZL, Chintala SK, York JE, et al. Expression and role of matrix metalloproteinases MMP-2 and MMP-9 in human spinal column tumors. Clin Exp Metastasis 1998; 16: 721-8.

[28] Kumta SM, Huang L, Cheng YY, et al. Expression of VEGF and MMP-9 in giant cell tumor of bone and other osteolytic lesions. Life Sci 2003; 73: 1427-36

[29] Lee SK, Lorenzo J. Cytokines regulating osteoclast formation and function. Curr Opin Rheumatol 2006; 18: 411-8.

[30] Rao VH, Bridge JA, Neff JR, et al. Expression of $72 \mathrm{kDa}$ and 92 $\mathrm{kDa}$ type IV collagenases from human giant-cell tumor of bone. Clin Exp Metastasis 1995; 13: 420-6.

[31] Rao VH, Singh RK, Bridge JA, et al. Regulation of MMP-9 (92 $\mathrm{kDa}$ type IV collagenase/gelatinase B) expression in stromal cells of human giant cell tumor of bone. Clin Exp Metastasis 1997; 15: 400-9.

[32] Shingleton WD, Hodges DJ, Brick P, et al. Collagenase: a key enzyme in collagen turnover. Biochem Cell Biol 1996; 74: 759-75.

[33] Teti A, Farina AR, Villanova I, et al. Activation of MMP-2 by human GCT23 giant cell tumour cells induced by osteopontin, bone sialoprotein and GRGDSP peptides is RGD and cell shape change dependent. Int J Cancer 1998; 77: 82-93.

[34] Uchida M, Shima M, Shimoaka T, et al. Regulation of matrix metalloproteinases (MMPs) and tissue inhibitors of metalloproteinases (TIMPs) by bone resorptive factors in osteoblastic cells. J Cell Physiol 2000; 185: 207-14

[35] Ueda Y, Imai K, Tsuchiya H, et al. Matrix metalloproteinase 9 (gelatinase B) is expressed in multinucleated giant cells of human giant cell tumor of bone and is associated with vascular invasion. Am J Pathol 1996; 148: 611-22.

[36] Viguet-Carrin S, Garnero P, Delmas PD. The role of collagen in bone strength. Osteoporos Int 2006; 17: 319-36.

[37] Ghert M, Simunovic N, Cowan RW, et al. Properties of the stromal cell in giant cell tumor of bone. Clin Orthop Relat Res 2007; 459: 8-13.

[38] Komiya S, Inoue A. Cementation in the treatment of giant cell tumor of bone. Arch Orthop Trauma Surg 1993; 112: 51-5.

[39] Nishimura M, Yuasa K, Mori K, et al. Cytological properties of stromal cells derived from giant cell tumor of bone (GCTSC) which can induce osteoclast formation of human blood monocytes without cell to cell contact. J Orthop Res 2005; 23: 979-87.

[40] Rao VH, Singh RK, Delimont DC, et al. Interleukin-1beta upregulates MMP-9 expression in stromal cells of human giant cell tumor of bone. J Interferon Cytokine Res 1999; 19: 1207-17.

[41] Sasaguri Y, Komiya S, Sugama K, et al. Production of matrix metalloproteinases 2 and 3 (stromelysin) by stromal cells of giant cell tumor of bone. Am J Pathol 1992; 141: 611-21.

[42] Wen J, Xie D, Yao J. [Promotive effect of TNF-alpha and M-CSF on osteolysis induced by giant cell tumor of bone]. Zhonghua Bing Li Xue Za Zhi 1997; 26: 273-6.

[43] Wen J, Xie D, Yao J, et al. Effect of cytokines on in vitro bone resorption by cells isolated from giant cell tumor of bone. Chin Med J (Engl) 1999; 112: 443-7.

(C) Rabinovich et al.; Licensee Bentham Open.

This is an open access article licensed under the terms of the Creative Commons Attribution Non-Commercial License (http://creativecommons.org/licenses/bync/3.0/), which permits unrestricted, non-commercial use, distribution and reproduction in any medium, provided the work is properly cited. 